Acta vet. scand. $1974,15,90-99$.

From the Department of Clinical Biochemistry, Royal Veterinary College, Stockholm, Sweden, and the Department of Physiology, Veterinary College of Norway, Oslo, Norway.

\title{
DIURNAL VARIATION OF PERIPHERAL PLASMA LEVELS OF TESTOSTERONE IN BULLS MEASURED BY A RAPID RADIOIMMUNOASSAY PROCEDURE*
}

\author{
By \\ Prakash Chandra Sanwal * , Anne Sundby and Lars-Eric Edquist
}

SANWAL, PRAKASH CHANDRA, ANNE SUNDBY and LARS-ERIC EDQVIST: Diurnal variation of peripheral plasma levels of testosterone in bulls measured by a rapid radioimmunoassay procedure. Acta vet. scand. $1974,15,90-99$. - A radioimmunoassay technique, using antibodies to testosterone-3-(O-carboxymethyl) oxime-bovine serum albumin, has been applied for the measurement of peripheral plasma levels of testosterone in bulls. The individual as well as the mean 24-hr. pattern of peripheral plasma levels of testosterone in the four bulls investigated showed three distinct peaks. The mean peripheral plasma level of testosterone peaked around 10 p.m., around 6 a.m. and around noon, the mean levels obtained at these times being $6.2,6.1$ and $4.2 \mathrm{ng} / \mathrm{ml}$, respectively. In one bull an additional peak occurred around 2 a.m. $(8.2 \mathrm{ng} / \mathrm{ml})$. Significantly lower peripheral plasma levels of testosterone were observed between the peak values.

testosterone; blood; radioimmunoassay; bulls.

The recent development of radioimmunoassay techniques for the measurement of peripheral plasma levels of various steroids made possible serial determinations of these compounds. Such techniques have been proved to work with a high degree of specificity and sensitivity (Edqvist \& Johansson 1972a).

* This study was supported by the Agricultural Research Council of Norway and the Swedish Council for Forestry and Agricultural Research.

* * Present address: Department of Physiology and Endocrinology, Indian Veterinary Research Institute, Izatnagar, U.P., India. 
In veterinary medicine these methods have been of special value, since the tedious and difficult procedure of quantitative urine collections from animals is avoided.

The purpose of the present investigation was to develop and apply a radioimmunoassay technique for the study of the diurnal variation of peripheral plasma levels of testosterone* in bulls.

\section{MATERIAL}

Four fertile bulls of the Norwegian Red Breed maintained at Stensby Artificial Insemination Centre were studied. The age of the bulls was two years and their weights ranged between 710 and $800 \mathrm{~kg}$.

Blood was collected into heparinized tubes every hour during a 24-hr. period. In order to minimize external stress on the animals, blood samples were withdrawn via indwelling cannulas in the jugular vein. All bulls were sampled on the 7th and 8th December 1972. The jugular catheter was flushed with a heparin/saline solution before and after each collection. The blood was centrifuged immediately after collection. Plasma was removed and stored in a freezer at below $-15^{\circ} \mathrm{C}$ until analysed.

* The following abbreviations and trivial names are used:

Aldosterone: 11 $\beta, 21$-dihydroxy-4-pregnene-3,18,20-trione.

Androstanedione: $5 \alpha$-androstan-3,17-dione.

Androstenedione: 4-androsten-3,17-dione.

Androsterone: $3 \alpha$-hydroxy-5 $\alpha$-androstan-17-one.

Cortisol: $11 \beta, 17 \alpha, 21$-trihydroxy-4-pregnene-3,20-dione.

Corticosterone: $11 \beta, 21$-dihydroxy-4-pregnene-3,20-dione.

Dehydroisoandrosterone: $3 \beta$-hydroxy-5-androsten-17-one.

$5 \alpha$-dihydrotestosterone: $17 \beta$-hydroxy-5 $\alpha$-androstan-3-one.

Epiandrosterone: $3 \beta$-hydroxy-5 $\alpha$-androstan-17-one.

Etiocholanolone: $3 \alpha$-hydroxy-5 $\beta$-androstan-17-one.

$11 \beta$-hydroxyetiocholanolone: $3 \alpha, 11 \beta$-dihydroxy-5 $\beta$-androstan-17-one.

11-ketoandrosterone: $3 \alpha$-hydroxy-5 $\alpha$-androstan-11,17-dione.

11-ketoetiocholanolone: $3 \alpha$-hydroxy-5 $\beta$-androstan-11,17-dione.

Estradiol-17 $\beta$ : 1,3,5(10)-estratriene-3,17 $\beta$-diol.

Estradiol-17 $\alpha: 1,3,5(10)$-estratriene-3,17 $\alpha$-diol. .

Estriol: 1,3,5(10)-estratriene-3,16 $\alpha, 17 \beta$-triol.

Estrone: 3-hydroxy-1,3,5(10)-estratriene-17-one.

Progesterone: 4-pregnene-3,20-dione.

$17 \alpha$-hydroxyprogesterone: $17 \alpha$-hydroxy-4-pregnene-3,20-dione.

S.A.: Specific activity.

s: Standard deviation.

s.e.m.: Standard error of the mean.

Testosterone: $17 \beta$-hydroxy-4-androsten-3-one. 


\section{METHODS}

The solvents, reagents, buffers and equipments used were the same as have been described previously for the radioimmunoassay of peripheral plasma levels of estrone and estradiol-17 $\beta$ (Edqvist \& Johansson 1972a, b).

\section{Steroids}

1,2,6,7-3 ${ }^{3}$-testosterone (S.A. $91 \mathrm{Ci} / \mathrm{mM}$ ) was obtained from New England Nuclear Corp., USA. All nonradioactive steroids used were purchased from Ikapharm, Israel. The steroids were diluted with ethanol and stored at below $-15^{\circ} \mathrm{C}$.

\section{Antiserum}

One rabbit was immunized with testosterone-3-(O-carboxymethyl)oxime-bovine serum albumin prepared according to Erlanger et al. $(1958,1967)$. The schedule of immunizations and bleedings has been described elsewhere (Martinsson et al. 1973). The rabbit responded with an antibody titre after three months of immunization. The antiserum was used in a dilution of 1:200, yielding 2,000 assay units per $\mathrm{ml}$ of antiserum.

\section{Extraction}

In the present investigation diethyl ether was used for the extraction of the plasma samples. The extraction recovery was tested by adding known amounts of testosterone $(10-5,000 \mathrm{pg})$ to extraction tubes together with $32 \mathrm{pg}$ of tritiated testosterone ( $\sim 0.01 \mu \mathrm{Ci}$ ). The contents of the tubes were evaporated to dryness under a stream of air, and thereafter were added to each tube different amounts of plasma $(100-500 \mu \mathrm{l})$ obtained from castrated pigs or ovariectomized sows and cows. Thereafter the tubes were incubated at $37^{\circ} \mathrm{C}$ for 15 min. and extracted by shaking for $1 \mathrm{~min}$. with 10 vol. of diethyl ether. It was found, when using $100 \mu$ l of plasma, that the extraction recovery was lowered and less precise $(82.5 \%, \mathrm{~s} 4.7 \%)$ as compared to the results obtained for the extraction of $0.5 \mathrm{ml}$ of plasma $(86.3 \%$, s $3.3 \%$ ). However, when using $2 \mathrm{ml}$ of diethyl ether for the extraction of $100 \mu \mathrm{l}$ of plasma, recoveries comparable to those obtained for the extraction of $0.5 \mathrm{ml}$ of plasma were encountered $(85.4 \%$, s $3.3 \%)$.

In this investigation 10 vol., but not less than $2 \mathrm{ml}$ of diethyl ether, have been used for the extraction of the plasma samples. No significant differences were found for the various amounts of testosterone added or different plasmas used. All extraction recoveries have subsequently been summarized in Table 1 . The mean recovery gives a correction factor of 1.15 . Owing to the relatively high precision for the extraction step the use of an internal standard has not been necessary. 
T a b l e 1. Procedural losses for the diethyl ether extraction step.

\begin{tabular}{cccc}
\hline $\begin{array}{c}\text { Percentage } \\
\text { recovery }\end{array}$ & s & $\begin{array}{c}\text { Coefficient } \\
\text { of variation }(\%)\end{array}$ & n \\
\hline 86.4 & 3.7 & 4.3 & 71 \\
\hline
\end{tabular}

\section{Radioimmunoassay}

To the dried diethyl ether fraction was added $0.1 \mathrm{ml}$ of antibody (1:200) and $300 \mathrm{pg}$ of tracer in $0.1 \mathrm{ml}$ phosphate-buffered saline (pH 7.0) containing $0.1 \%$ gelatin. Standard samples of testosterone ranging from 0 to $5 \mathrm{ng}$ were assayed in duplicate together with the experimental samples. For further details on the radioimmunoassay system, see Edqvist \& Johansson (1972a, b).

The concentration of testosterone in the unknown samples was interpolated from the standard curve, corrected for procedural losses (factor 1.15) and expressed in $\mathrm{ng}$ per $\mathrm{ml}$ of plasma.

\section{Sensitivity}

When applying the $95 \%$ confidence limit, $10 \mathrm{pg}$ of testosterone differed significantly from zero. However, when assaying $100 \mu \mathrm{l}$ of bovine ovariectomized plasma a mean value of $30 \mathrm{pg}$ as read off the standard curve was obtained. Therefore all values below $0.3 \mathrm{ng} / \mathrm{ml}$ are considered to be below the practical detection limit of the assay when $100 \mu \mathrm{l}$ of plasma is extracted. If such values are obtained the samples are rerun in a more sensitive system using an antibody dilution of 1:600 and $30 \mathrm{pg}$ of tracer. Typical standard curves for the assay are shown in Fig. 1.

\section{Specificity}

The specificity of the antibody was tested by cross-reaction studies using various steroids. Percentage cross-reaction was calculated according to Thorneycroft et al. (1970). Of the steroids tested, only $5 \alpha$-dihydrotestosterone was found to give a significant cross-reaction (40\%, Table 2). Peripheral plasma levels of testosterone as measured by the present technique have been shown to agree favourably when compared to values obtained using gas-liquid chromatography (to be published).

\section{Precision}

The precision of the method was calculated from duplicate plasma samples (Table 3). Fig. 1 also shows the $95 \%$ confidence limits for the mean of nine duplicate standard curves randomly selected. 
Table 2. Cross-reaction of various steroids in the radioimmunoassay system.

\begin{tabular}{|c|c|}
\hline & $\begin{array}{c}\text { Cross-reaction } \\
\%\end{array}$ \\
\hline \multicolumn{2}{|l|}{$C_{21}$ Steroids } \\
\hline Cortisol & $<0.4$ \\
\hline Corticosterone & $<0.4$ \\
\hline Progesterone & $<0.4$ \\
\hline 20ß-hydroxy-4-pregnene-3-one & $<0.4$ \\
\hline $20 \alpha$-hydroxy-4-pregnene-3-one & $<0.4$ \\
\hline $17 \alpha$-hydroxyprogesterone & $<0.4$ \\
\hline Aldosterone & $<0.4$ \\
\hline \multicolumn{2}{|l|}{$C_{19}$ Steroids } \\
\hline Testosterone & 100.0 \\
\hline $5 \alpha$-dihydrotestosterone & 40.0 \\
\hline Androstenedione & 1.8 \\
\hline Androstanedione & 0.4 \\
\hline Dehydroisoandrosterone & $<0.4$ \\
\hline Etiocholanolone & $<0.4$ \\
\hline 11-ketoetiocholanolone & $<0.4$ \\
\hline $11 \beta$-hydroxyetiocholanolone & $<0.4$ \\
\hline Androsterone & $<0.4$ \\
\hline Epiandrosterone & $<0.4$ \\
\hline 11-ketoandrosterone & $<0.4$ \\
\hline $5 \beta$-androstan-3,11,17-trione & $<0.4$ \\
\hline $5 \beta$-androstan-3,17-dione & $<0.4$ \\
\hline \multicolumn{2}{|l|}{$C_{18}$ Steroids } \\
\hline Estrone & $<0.4$ \\
\hline Estradiol-17 $\beta$ & $<0.4$ \\
\hline Estradiol-17 $\alpha$ & $<0.4$ \\
\hline Estriol & $<0.4$ \\
\hline
\end{tabular}

\section{RESULTS}

In Fig. 2 is shown the individual as well as the mean 24-hr. pattern of peripheral plasma levels of testosterone in the four bulls investigated. A cyclic pattern of the testosterone levels was found in all bulls. The mean peripheral plasma level of testosterone peaked around 10 p.m., around 6 a.m. and finally around noon (Fig. 2), the mean levels obtained at these times being 6.2, 6.1 and $4.2 \mathrm{ng} / \mathrm{ml}$ respectively. Significantly lower peripheral 
plasma levels of testosterone were observed between the peak values. At 4 p.m. the mean value was $2.2 \mathrm{ng} / \mathrm{ml}$, at 2 a.m. it was $2.9 \mathrm{ng} / \mathrm{ml}$, and at 9 a.m. $1.8 \mathrm{ng} / \mathrm{ml}$.

In one bull an additional peak occurred around 2 a.m. (Fig. 2). The highest level then measured was $8.2 \mathrm{ng} / \mathrm{ml}$, decreasing to

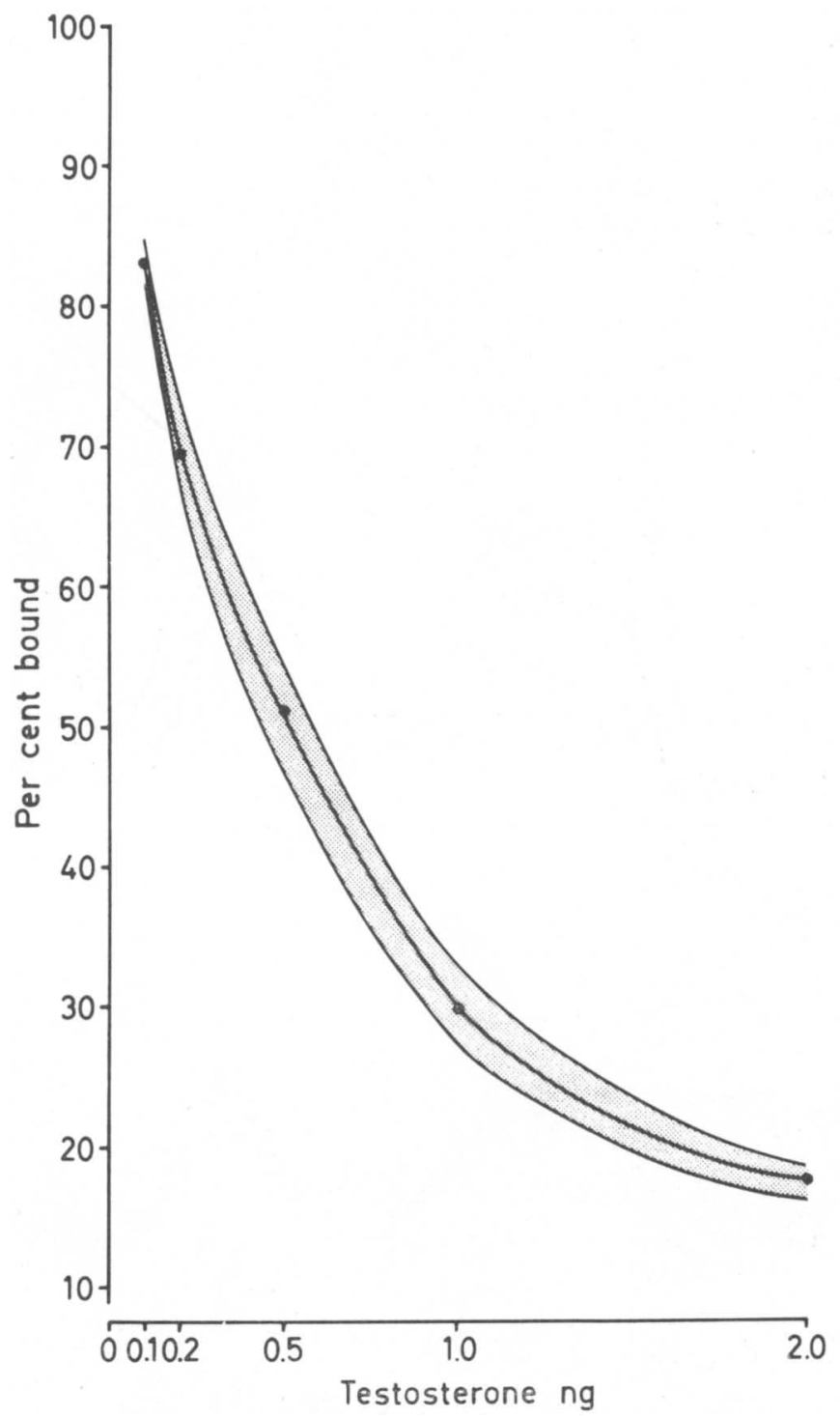

Figure 1. The $95 \%$ confidence limits for the mean of nine duplicate standard curves. The zero point has arbitrarily been calculated as $100 \%$ bound steroid. 
$2.7 \mathrm{ng} / \mathrm{ml}$ at 3 a.m. Thereafter the pattern of this bull followed that of the other three bulls investigated, thus showing three peaks of testosterone during the 24-hr. period investigated.

Table 3. The precision of the testosterone measurements.

\begin{tabular}{rcccc}
\hline $\begin{array}{c}\text { Range } \\
(\mathrm{ng})\end{array}$ & $\begin{array}{c}\text { Mean } \\
(\mathrm{ng})\end{array}$ & $\mathrm{s}$ & $\begin{array}{c}\text { Coefficient } \\
\text { of variation (\%) }\end{array}$ & $\begin{array}{c}\text { Number of } \\
\text { duplicate } \\
\text { determinations }\end{array}$ \\
\hline $0.3-1.0$ & 0.75 & 0.26 & 34.7 & 13 \\
$1.1-3.0$ & 2.08 & 0.35 & 16.7 & 57 \\
$3.1-7.0$ & 5.14 & 0.54 & 10.5 & 62 \\
$7.1-10.0$ & 8.30 & 0.91 & 11.0 & 30 \\
$>10.0$ & 15.26 & 1.16 & 7.6 & 18 \\
\hline
\end{tabular}

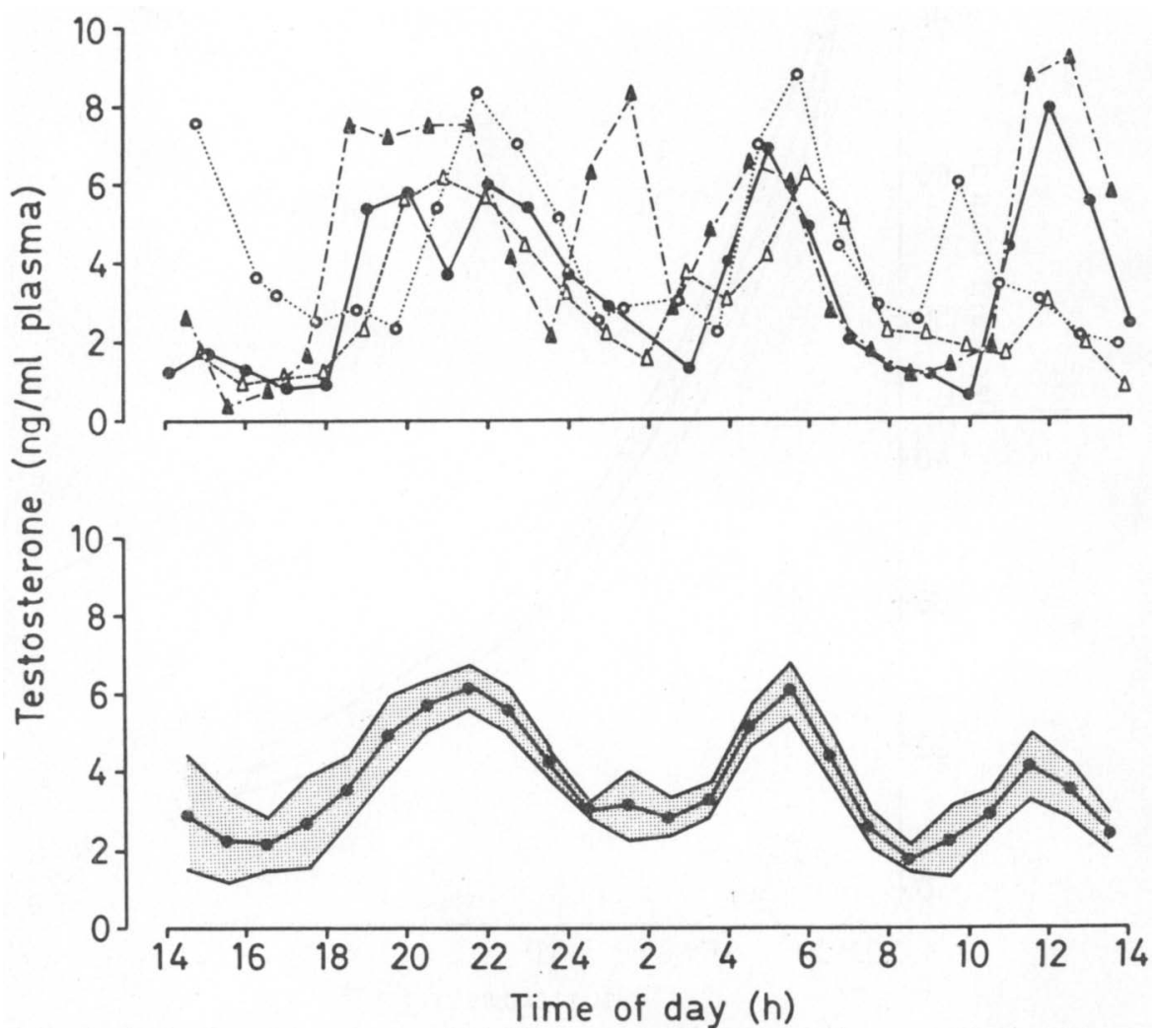

F i g u r e 2. (Above) Peripheral plasma levels of testosterone in four bulls. (Below) m. \pm s.e.m. 


\section{DISCUSSION}

Antibodies to testosterone obtained after immunization with testosterone-3-(O-carboxymethyl)oxime-bovine serum albumin have previously been shown to cross-react to various degrees with $5 \alpha$-dihydrotestosterone (Furuyama et al. 1970, Coyotupa et al. 1972), as also found in the present investigation. The radioimmunoassay system here applied does not include isolation and purification of the extracted testosterone. Thus interference from, e.g., $5 \alpha$-dihydrotestosterone is very likely. When comparing data obtained by the present technique and by gas-liquid chromatography, a high degree of correlation was found for blood samples from humans (to be published).

When using competitive protein binding for the assay of peripheral plasma levels of testosterone, some form of time-consuming purification step of the plasma extract must be applied, since the affinity of the protein to, e.g., $5 \alpha$-dihydrotestosterone is significantly higher than to testosterone itself (Vermeulen \& Verdonck 1970, Anderson 1970).

The very pronounced cyclical fluctuation of the peripheral plasma levels of testosterone reported here during the 24-hr. observation period is similar to the pattern previously described in bulls (Katongole et al. 1971). These authors investigated two bulls on two different occasions and found one bull to have four-five peaks and the other bull nine - ten peaks during both 24-hr. observation periods. In the present investigation a more uniform pattern of testosterone peaks was found in the four bulls investigated. All bulls showed three peaks at about the same time, and only one had an additional fourth peak.

The testosterone values reported by Katongole et al. using a competitive protein binding technique ranged from 2 to $20 \mathrm{ng} /$ $\mathrm{ml}$. In the present investigation the testosterone levels ranged from lowest values of 0.8 to highest of around $8 \mathrm{ng} / \mathrm{ml}$. This difference in the levels found might be due to the different techniques used for the measurement of testosterone. Factors such as light, season and breed of bull might also influence the level, as well as the pattern of peripheral plasma testosterone. The level found in the present investigation is about the same as reported in man by Coyotupa et al., viz. within the range 2.5-8.8 $\mathrm{ng}$ of testosterone per $\mathrm{ml}$ of serum.

Katongole et al. also measured the peripheral plasma levels of $\mathrm{LH}$ and found that the testosterone peaks were preceded by 
LH peaks. The exact mechanism behind the cyclic testosterone pattern in bulls is not known. Katongole et al. considered the cyclic $\mathrm{LH}$ release to be most likely due to some inherent central rhythm rather than to any on-off offect due to the negative feedback of testosterone. These authors also suggest that external stimuli, e.g. the sight of a cow and "teasing", can produce LH release in the bull by a neuro-endocrine reflex.

The diurnal variation of peripheral plasma levels of testosterone has to be taken into account when evaluating peripheral plasma levels of testosterone in bulls from randomly selected blood samples. It may be recommended to collect blood samples at a fixed hour every day or after the injection of gonadotrophin or gonadotrophin releasing hormone.

\section{ACKNOWLEDGEMENTS}

The technical assistance of Richard Tollman, D.V.M., is greatly appreciated.

\section{REFERENCES}

Anderson, D. C.: A simple and clinically useful method for plasma testosterone-like substances by competitive protein binding. Clin. chim. Acta 1970, 29, 513-522.

Coyotupa, J., A. F. Parlou \& G. E. Abraham: Simultaneous radioimmunoassay of plasma testosterone and dihydrotestosterone. Analyt. Letters 1972, 5, 329-340.

Edqvist, L. E. \& E. D. B. Johansson: Radioimmunoassay of oestrone and oestradiol in human and bovine peripheral plasma. Acta endocr. (Kbh.) 1972a, 71, 716-730.

Edqvist, L. E. \& E. D. B. Johansson: Radioimmunoassay and competitive protein binding for the measurement of certain steroid hormones in farm animals. In Isotope Studies on the Physiology of Domestic Animals, IAEA, Vienna 1972b, 245-258.

Erlanger, B. F., F. Borek, S. Beiser \& S. Liebermann: Preparation and characterization of conjugates of bovine serum albumin with testosterone and with cortisone. J. biol. Chem. 1958, 228, 713727.

Erlanger, B. F., S. M. Beiser, F. Borek, F. Edel \& S. Liebermann: In Methods in Immunology and Immunochemistry. Williams, C. A. and M. C. Chase, eds. Acad. Press Inc., New York 1967, Vol. I, pp. 144 and 151.

Furuyama, S., D. M. Mayes \& C. A. Nugent: A radioimmunoassay for plasma testosterone. Steroids 1970, 16, 415-428.

Katongole, C. B., F. Naftolin \& R. V. Short: Relationship between blood levels of luteinizing hormone and testosterone in bulls, and the effect of sexual stimulation. J. Endocr. 1971, 50, 457-466. 
Martinsson, K., P. Lindberg \& E. D. B. Johansson: Preparation of protein-steroid conjugates and antisera against oestradiol-17 $\beta$. Acta vet. scand. $1973,14,278-291$.

Thorneycroft, I. H., S. A. Tillson, G. E. Abraham, R. J. Scaramuzzi \& B. V. Caldwell: In Immunologic Methods in Steroid Determination. Peron, F. G. and B. V. Caldwell, eds. Appleton-CenturyCrofts, Education Division, Meredith Corporation, New York 1970, p. 63.

Vermeulen, A. \& L. Verdonck: Testosterone assays by competitive protein binding. Acta endocr. (Kbh.) 1970, Suppl. No. 147, 239-256.

\section{SAMMANFATTNING}

Dygnsvariationen av blodplasmanivåer av testosteron hos tjur mätt med en radioimmunologisk metod.

En radioimmunologisk metod, utnyttjande antikroppar mot testosteron-3-(0-carboyxmetyl) oxim-bovint serum albumin, har applicerats för bestämning av plasma nivåer av testosteron hos tjur. Hos samtliga fyra tjurar, som undersöktes med provtagningar under 24 timmar, uppvisade plasmanivåerna av testosteron ett gemensamt mönster med tre distinkta koncentrationsökningar. Medelplasmanivån av testosteron var högst omkring kl. 22, omkring kl. 6 och omkring kl. 12. Medelnivåerna vid dessa tillfällen var respektive $6,2,6,1$ och $4,2 \mathrm{ng} /$ $\mathrm{ml}$. En tjur uppvisade även en koncentrationsökning omkring kl. 14 $(8,2 \mathrm{ng} / \mathrm{ml})$. Signifikant lägre plasma nivåer av testosteron uppmättes på tidpunkter mellan de höga testosteronvärdena.

(Received September 20, 1973).

Reprints may be requested from: Lars-Eric Edqvist, Department of Canical Biochemistry, Royal Veterinary College, S-104 05 Stockholm 50, Sweden. 